\title{
Conceptual foundations of entrepreneurial strategy: A systematic literature review
}

\author{
Lidia Branco, João Ferreira, Shital Jayantilal
}

\begin{abstract}
A B S T R A C T
Objective: The objective of the article is to contribute to a greater and deeper understanding of the ES conceptualisation. The relevance of the topic of Entrepreneurial Strategy (ES) stems from growing interest of society in entrepreneurship, which has become extensively discussed although the concept of ES is still poorly understood.

Research Design \& Methods: A systematic literature review (SLR) referring to 427 articles from the Web of Science and Scopus databases was conducted.

Findings: The results made it possible to identify five ES conceptual foundations: i) economic theory and entrepreneurship; ii) entrepreneurial strategies, concept - theory; iii) entrepreneurial strategies, framework - models; iv) entrepreneurial strategies, contexts - application; and v) entrepreneurial strategies, application - metrics.

Implications \& Recommendations: This SLR can help to highlight the gap in theories on ES, its conceptualisation and the fundamentals found in the literature. A research agenda is suggested for each ES foundation identified.

Contribution \& Value Added: The study is innovative given there have been no other identified SLR studies on the ES concept. The study attempts to contribute towards the literature by offering a model of interactions of the ES foundations.

Article type: theoretical article

Keywords: entrepreneurial strategy; conceptualisation; entrepreneurship; strategy; systematic lit-

JEL codes: erature review

L26, M01, M21

Received: 7 January 2021 Revised: 11 March 2021 Accepted: 16 March 2021
\end{abstract}

\section{Suggested citation:}

Branco, L., Ferreira, J., \& Jayantilal, S. (2021). Conceptual foundations of entrepreneurial strategy: A systematic literature review. Entrepreneurial Business and Economics Review, 9(3), 103-118. https://doi.org/10.15678/EBER.2021.090307

\section{INTRODUCTION}

The importance of the topic of entrepreneurial strategy (ES) has increased in recent years, whether in the microeconomic framework for the analysis of enterprise performance or in a broader macroeconomic framework of growth and economic development of countries. Several authors agree that the development of ES in firms places them in positions to regularly and systematically recognize and exploit entrepreneurial opportunities, and it is a "path to success" (Ireland, Covin, \& Kuratko, 2009). Ireland et al. (2009) report that ES fosters the renewal of businesses and makes them more innovative, and it enables innovation, creativity, and making responsible decisions (Meyer \& Heppard, 2000).

In the last few decades, bigger and bigger growth in the entrepreneurial spirit of economic agents has been witnessed, both at the individual level and at the level of organisations, which has contributed to the research on entrepreneurial strategies (ES) and increased attention of the academic world. Murray (1984) was one of the first authors to develop a reflection on the ES conceptualisation, character, and stimuli to entrepreneurial behaviour. According to the author, an ES is how a firm defines and redefines its core set 
of connections with the environment in which it operates. Globalisation and consequently more and more dynamic market has required from companies to adopt more proactive and entrepreneurial behaviour, and thus the adoption of an ES has become a mandatory path for the success of organisations (Morris, Kuratko, \& Covin, 2008). ES involves employing a method to manage entrepreneurship (Ireland et al., 2009; Morris et al., 2008) to find a viable goal in the economic ecosystem and define a coherent path to achieve it. According to Kuratko and Audretsch (2009), strategy attempts to capture where the firm wants to go and how it plans to get there. When entrepreneurship is introduced to strategy, the possibilities regarding where the firm can go, how fast, and how it gets there are greatly enhanced.

An effective ES involves a proactive search for new opportunities and requires effective management of innovation processes that will bring value to the company, processes based on three dimensions of the Entrepreneurial Orientation (EO) that were historically identified (Miller, 1983) as characterising the strategic attitude of the company: innovativeness, proactiveness, and risk-taking. More recently, Wales (2016) found that EO has become one of the most established constructs in entrepreneurship as the subject of extensive research. Entrepreneurial orientation was defined in various ways in previous research. For example, Anderson, Covin, and Slevin (2009) present a succinct definition of EO: company decision-making, practices, management philosophies, and strategic behaviour of entrepreneurial nature. Zhang (2017) defines ES as a construct that specifically discloses the company's EO (Ireland et al., 2009), and it is perceived as a potential source of competitive advantage of firms.

However, despite entrepreneurship being the object of different theoretical approaches, especially concerning the dominant approach that emphasizes analysis (innovation, leadership, organisation, knowledge, culture, psychology, etc.), from the literature we conclude that they all share the idea that the phenomenon always comes within the creation/development of business activities as a result of identifying opportunities and their operation (Companys \& McMullen, 2007).

All the approaches also share the basic assumption that entrepreneurship is a phenomenon that can only be conceptualised in a multifactorial way, since it is undoubtedly conditioned by various external social factors (context variables). Its genesis cannot just be explained by recourse to the analysis grid of economic theory. This is the focus adopted by various articles studied, in addition to the economic matrix, other causalities of institutional, cultural and even psychological nature, arguing that the emergence of entrepreneurship takes place with the backdrop of a complex network of social relations which will determine the profile of the interactions among the entrepreneur, resources and opportunities (Xiao, 2015; Khan, Li, Safdar, \& Khan, 2019). Much has been discussed about what an ES can do for a company (Ireland, Covin, \& Kuratko, 2009; Ireland, Hitt, Camp, \& Sexton, 2001). Zahra, Jennings, and Kuratko (1999) highlighted the demand to survey different ES conceptions at the company level. Previous studies have shown that despite its importance and a potential source of competitive advantage for companies, an exact conceptualisation of ES has been vague (Ireland, Covin, \& Kuratko, 2009; Meyer \& Heppard, 2000). Many scholars and academics have defined ES differently and through various approaches (Ireland, Covin, \& Kuratko, 2009; Drucker, 1985; Murray, 1984).

In this context, an ES has a conceptual breadth that goes beyond the so-called corporate entrepreneurship - when the focus is on companies' internal renewal strategies, as a result of the adaptation of the organisation in response to markets and/or competitors (Kuratko \& Audretsch, 2013) or when the focus is on the renovation/ expansion process through the acquisition of small companies, but from innovative sources (corporate ventures) (Hind \& Steyn, 2015).The vast majority of research lacks systematisation and categorisation.

Undertaking a systematic review of literature in its fragmented field provides the opportunity to pose the following research questions:

RQ1: What are entrepreneurial strategies?

RQ2: How are they and their fundamentals conceptualised in the more general framework of economic theory?

The answer to these research questions makes a contribution to the clarification of the concept of ES and the construction of explanatory categories of the conceptual foundations of entrepreneurial strategies. 
There is a relevant need to systematise research on what entrepreneurial strategies are and on their conceptualisation to further advance and summarise different approaches in this research area. Therefore, this study aims to fill this gap, thus contributing to a greater and deeper understanding of an ES and its conceptual foundations. Thus, we aim to identify the most dominant approaches in the literature and define a research agenda based on a systematic literature review to discuss the application of the concept of ES in the most diverse contexts.

First, we will present the methodology and the method, then the following part is dedicated to conceptual foundations of entrepreneurial strategies and the construction of explanatory categories. Next, the conclusions are presented and discussed and some topics are proposed to a new research agenda.

\section{MATERIAL AND METHODS}

We followed the process of a systematic literature review (SRL) proposed by Denyer and Tranfield (2009) and Nolan and Garavan (2016). In this context, the general methodological characteristics of a SLR reflect epistemology that stipulates that knowledge should be acquired through scientific objectives, using an impartial process (Denyer \& Tranfield, 2009). In this regard, Denyer and Tranfield (2009) set the SLR as a specific methodology that locates existing studies, selects and evaluates contributions, analyses and synthesizes data, and reports evidence in such a way that it allows reasonably clear conclusions to be reached about what is and what is not known on the topic being investigated.

Using the Scopus and Web of Science databases and aiming to create a comprehensive database about Entrepreneurial Strategy (ES) and its conceptualisation, documents were identified by using the search terms "entrepren* strateg*". To these search terms we applied the following filters: language (English), type of document (articles and scientific publications), and subject categories (Management, Business, Economics). At the beginning, 427 documents were identified that could somehow be connected with ES. Faced with such a broad spectrum of results, the documents were divided into two broad categories: i) those located essentially within a theoretical framework, and; ii) those run by empirical studies as the basis for the concept definition, whether eminently qualitative or quantitative. In this regard, various models and analysis grids, instruments, and performance measures were used, and the results aimed to validate some of the advanced conceptual assumptions. This procedure yielded a process of the selection and validation, whose synthesis is schematically summarised in Figure 1.

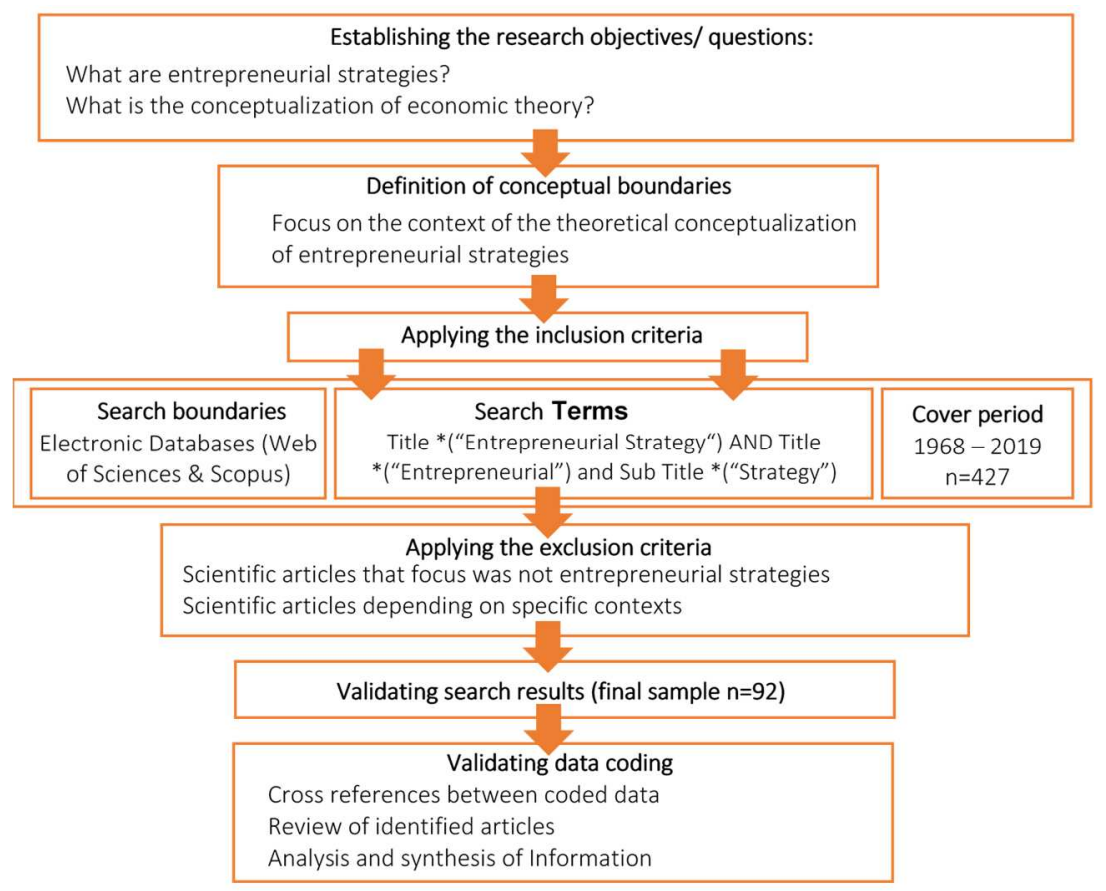

Figure 1. Steps of the SLR Process Source: own elaboration. 
After applying the principles and criteria mentioned above, we reached the final sample of 92 documents (Table 1).

Table 1. Typology of documents obtained in the study

\begin{tabular}{|c|c|c|c|}
\hline Entrepreneurial Strategy (ES) & No. of Articles & \% Sample & $\%$ Total \\
\hline Economic Theory and Entrepreneurship (ETE) & 12 & $13.04 \%$ & $2.81 \%$ \\
\hline Concepts - Theory (CT) & 30 & $32.61 \%$ & $7.03 \%$ \\
\hline Framework - Models (FM) & 14 & $15.22 \%$ & $3.28 \%$ \\
\hline Contexts - Application (CA) & 14 & $15.22 \%$ & $3.28 \%$ \\
\hline Application - Metrics (AM) & 22 & $23.91 \%$ & $5.15 \%$ \\
\hline Total & 92 & $100 \%$ & $21.55 \%$ \\
\hline
\end{tabular}

Source: own study.

\section{Descriptive Analysis}

Figure 2 shows the evolution of publications over the period under analysis (1968-2019). The number of publications in this field has grown significantly since the late 60 s of the last century.

10

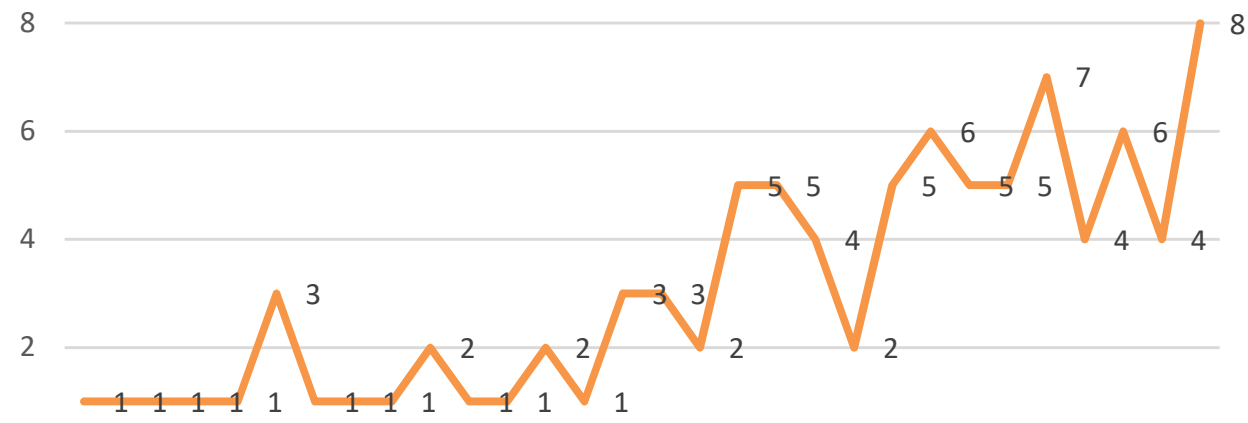

0

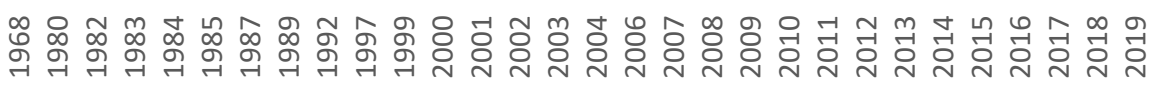

Figure 2. Timeline of the number of publications (1968-2019) Source: own elaboration.

By studying the number of articles per year, the results show that research on ES increased significantly in the last decade. In 2010-2019, 52 articles were published, a much larger number than the number of articles published in the previous 41 years (40 items between 1968-2009). Therefore, over $57 \%$ of the ES area published appeared in the last nine years. Table 3 shows the journals with the most published studies (top 20) on the ES topic and identifies the study type. The Strategic Management Journal leads with five articles, followed by Small Business Economics and Entrepreneurship: Theory and Practice, both with four published articles.

The majority of studies are theoretical (62\%), and only $38 \%$ are empirical. Qualitative studies represent $8 \%$ and quantitative studies $30 \%$. Table 4 shows the most cited articles (top 15). The article most cited is Miller's (1983) article, with 1813 citations. This article is followed by Miller and Friesen (1982) article with 1163 citations, and Hitt et al. (2001) with 679 citations. Additionally, another aspect to emphasise is that about $53 \%$ of these articles correspond to US publications. This percentage is more than six times higher in comparison with the country on the next position, namely, the United Kingdom (8.7\%).

In view of the diversity of the selected articles, only the work of the construction of a classification instrument could lead us to: 1) discovering possible theoretical contact bridges; 2) discovering possible similarities in the theoretical conception of ES; 3) progress - from 1) and 2) towards the construction of the answer to our essential starting question, that is, what entrepreneurial strategies are. And that was exactly the methodological approach we followed. 
Table 3. The list of top 20 journals

\begin{tabular}{|c|c|c|c|c|c|}
\hline \multirow{3}{*}{ No. } & \multirow{3}{*}{ Journal } & \multirow{3}{*}{$\begin{array}{c}\text { Number of } \\
\text { Articles }\end{array}$} & \multicolumn{3}{|c|}{ Type of research } \\
\hline & & & \multicolumn{2}{|c|}{ Empirical } & \multirow{2}{*}{ Conceptual } \\
\hline & & & Qual & Quant & \\
\hline 1 & Strategic Management Journal & 5 & 0 & 2 & 3 \\
\hline 2 & Small Business Economics & 4 & 0 & 2 & 2 \\
\hline 3 & Entrepreneurship: Theory and Practice & 4 & 0 & 2 & 2 \\
\hline 4 & Business Horizons & 3 & 0 & 1 & 2 \\
\hline 5 & Strategic Entrepreneurship Journal & 3 & 0 & 1 & 2 \\
\hline 6 & Technological Forecasting and Social Change & 2 & 0 & 1 & 1 \\
\hline 7 & International Journal of Management Reviews & 2 & 0 & 1 & 1 \\
\hline 8 & Mediterranean Journal of Social Sciences & 2 & 0 & 2 & 0 \\
\hline 9 & International Small Business Journal & 2 & 0 & 1 & 1 \\
\hline 10 & Handbook on Organizational Entrepreneurship & 2 & 0 & 0 & 2 \\
\hline 11 & International Small Business Journal & 2 & 0 & 0 & 2 \\
\hline 12 & International Entrepreneurship and Management Journal & 1 & 0 & 0 & 1 \\
\hline 13 & Management Science & 1 & 0 & 0 & 1 \\
\hline 14 & Journal of Small Business Strategy & 1 & 0 & 0 & 1 \\
\hline 15 & Journal of Small Business Management & 1 & 0 & 1 & 0 \\
\hline 16 & The Wiley Handbook of Entrepreneurship & 1 & 1 & 0 & 0 \\
\hline 17 & regional Studies & 1 & 0 & 1 & 0 \\
\hline 18 & Journal of Business Research & 1 & 0 & 0 & 1 \\
\hline 19 & Management Science & 1 & 0 & 0 & 1 \\
\hline 20 & The American Economic Review & 1 & 0 & 0 & 1 \\
\hline & Total & 40 & 1 & 15 & 24 \\
\hline
\end{tabular}

Source: own study.

\section{LITERATURE REVIEW AND THEORY DEVELOPMENT}

In the review of the selected documents, we identified five main entrepreneurial strategies (ES) foundations (Table 4), namely: 1) Economic Theory and Entrepreneurship (ETE): debating the role and foundations of entrepreneurship integration in economic theory; 2 ) Concept and Theory (CT): proposing a full discussion and theoretical, conceptual framework for Entrepreneurial Strategies; 3) Frameworks and Models (FM): discussing and presenting models and tools for the assessment of Entrepreneurial Strategies; 4) Contexts and Applications (CA): for debating and/or assessing the implementation of Entrepreneurial Strategies in the context variables function; 5) Application and Metrics (AM): quantitatively evaluating the result of the implementation of ES in the scope of their application in specific types of organisations, industries, or other specific contexts.

Table 4. Conceptualisation themes

\begin{tabular}{|c|c|c|}
\hline ES Categories & Conceptualisation & Authors \\
\hline \multirow{4}{*}{$\begin{array}{l}\text { (1) Economic } \\
\text { Theory and } \\
\text { Entrepreneur- } \\
\text { ship (ETE), } \\
\text { (N=12 docu- } \\
\text { ments) }\end{array}$} & $\begin{array}{l}\text { Integration of entrepreneurship in economic models and other varia- } \\
\text { bles that explain the factors that foster the emergence of entrepre- } \\
\text { neurial agents in an economy. }\end{array}$ & Baumol (1968) \\
\hline & $\begin{array}{l}\text { Concept of competitive advantage of companies implies the exist- } \\
\text { ence of SE strategies. }\end{array}$ & Porter (1980) \\
\hline & $\begin{array}{l}\text { Using an ES for the company to achieve the leadership in a new mar- } \\
\text { ket or a new industry through innovation. } \\
\text { Research into the nature, background, and effects of business entre- } \\
\text { preneurship. }\end{array}$ & $\begin{array}{l}\text { Drucker (1985) } \\
\text { Zahra, Jennings, \& Ku- } \\
\text { ratko (1999) }\end{array}$ \\
\hline & $\begin{array}{l}\text { Entrepreneurship is considered as a vital force in the economies of } \\
\text { countries. }\end{array}$ & $\begin{array}{l}\text { Audretsch \& Keilbach } \\
(2004)\end{array}$ \\
\hline
\end{tabular}




\begin{tabular}{|c|c|c|}
\hline ES Categories & Conceptualisation & Authors \\
\hline \multirow[t]{6}{*}{$\begin{array}{l}\text { (1) Economic } \\
\text { Theory and } \\
\text { Entrepreneur- } \\
\text { ship (ETE), } \\
\text { ( } \mathrm{N}=12 \text { docu- } \\
\text { ments) }\end{array}$} & $\begin{array}{l}\text { There is no room for entrepreneurial activities, an economy of pro- } \\
\text { duction, a perfect balance of information and scenario. } \\
\text { Entrepreneurship is crucial in building a sustainable competitive or- } \\
\text { ganisation in today's business environment. } \\
\text { Search for new directions of research into ES. }\end{array}$ & $\begin{array}{l}\text { Ott, Eisenhardt, Bingham } \\
(2006)\end{array}$ \\
\hline & $\begin{array}{l}\text { A framework of strategic entrepreneurship. } \\
\text { Entrepreneurship can lead companies to establishing competitive } \\
\text { advantages and creating wealth in today's competitive environment. }\end{array}$ & Foss \& Lyngsie (2011) \\
\hline & Individuals or companies carry out strategic entrepreneurship. & Djordjevic (2013) \\
\hline & $\begin{array}{l}\text { Entrepreneurship is decisive in getting better and more efficient } \\
\text { combinations of factors. } \\
\text { Relationship between the business model and the ES in a mature en- } \\
\text { vironment and applied to SMEs. }\end{array}$ & $\begin{array}{l}\text { Hoeyi \& Dzansi (2014) } \\
\text { Roaldsen (2015) }\end{array}$ \\
\hline & $\begin{array}{l}\text { Entrepreneurship is a state's or an organisation's quality and not an } \\
\text { anomaly, and entrepreneurial orientation manifests itself through } \\
\text { sustained entrepreneurial behaviour. }\end{array}$ & Wales (2016) \\
\hline & $\begin{array}{l}\text { Conceptualisation of ES through the matrix-based forms of corpo- } \\
\text { rate entrepreneurship. }\end{array}$ & Omotosho (2019) \\
\hline \multirow{11}{*}{$\begin{array}{l}\text { (2) Concept } \\
\text { and Theory } \\
(\mathrm{CT}),(\mathrm{N}=30 \\
\text { documents) }\end{array}$} & $\begin{array}{l}\text { Entrepreneur model assumes that innovation is always very high un- } \\
\text { less policymakers are advised to slow down. }\end{array}$ & Miller \& Friesen (1982) \\
\hline & $\begin{array}{l}\text { Discovery of the key determinants of entrepreneurship, the process } \\
\text { by which organisations are renewed by being pioneers, innovation, } \\
\text { and risk-taking. }\end{array}$ & Miller (1983) \\
\hline & Conceptualisation of ES. & Murray (1984) \\
\hline & $\begin{array}{l}\text { ES arises as a mutation process itself in the economic and technolog- } \\
\text { ical environment. }\end{array}$ & Dilts \& Prough (1987) \\
\hline & $\begin{array}{l}\text { Research into the nature, background, and effects of business entre- } \\
\text { preneurship. }\end{array}$ & $\begin{array}{l}\text { Zahra, Jennings, \& Ku- } \\
\text { ratko (1999) }\end{array}$ \\
\hline & $\begin{array}{l}\text { Definition of ES and an explanatory model directed essentially to the } \\
\text { existing businesses, corporate ES. }\end{array}$ & $\begin{array}{l}\text { Ireland, Covin, \& Kuratko } \\
(2009)\end{array}$ \\
\hline & Conceptual framework of entrepreneurship integrating strategy. & $\begin{array}{l}\text { Kuratko \& Audretsch } \\
(2009)\end{array}$ \\
\hline & $\begin{array}{l}\text { Synthesis of the conceptual evolution of corporate entrepreneur- } \\
\text { ship. }\end{array}$ & $\begin{array}{l}\text { Kuratko \& Audretsch } \\
(2013)\end{array}$ \\
\hline & $\begin{array}{l}\text { The essence of ESs is defined by individuals with a long-term view } \\
\text { and makes investments driven by a sense of duty and a belief in a fu- } \\
\text { ture vision, rather than short-term returns. } \\
\text { In this model, ES combined with an innovative character will mean } \\
\text { success and economic development. }\end{array}$ & Feldman (2014) \\
\hline & $\begin{array}{l}\text { Review of several authors discussing the conceptualisation of entre- } \\
\text { preneurial orientation and reviews of new directions of entrepre- } \\
\text { neurial orientation research. }\end{array}$ & Wales (2016) \\
\hline & Framework for the nature of the entrepreneurial choice process. & $\begin{array}{l}\text { Gans, Stern, \& Wu } \\
(2019)\end{array}$ \\
\hline \multirow{7}{*}{$\begin{array}{l}\text { (3) Frame- } \\
\text { works and } \\
\text { Models (FM) } \\
(\mathrm{N}=14 \text { docu- } \\
\text { ments) }\end{array}$} & Innovation models in different contexts. & Miller \& Friesen (1982) \\
\hline & Evaluation models are associated with an ES in the broadest sense. & Miller (1983) \\
\hline & Evaluation models associated with an ES depending on leadership. & Ray (1993) \\
\hline & Evaluation models associated with ES as innovation levels. & Sonfield \& Lussier (1997) \\
\hline & $\begin{array}{l}\text { Evaluation models associated with ES and their relationship to per- } \\
\text { formance. }\end{array}$ & $\begin{array}{l}\text { Dess, Lumpkin, \& Covin } \\
\text { (1997) }\end{array}$ \\
\hline & $\begin{array}{l}\text { Evaluation models associated with ESs, the macroeconomic impact } \\
\text { of these on the overall economy. }\end{array}$ & Werker (2003) \\
\hline & Evaluation models associated with an ES depending on leadership. & $\begin{array}{l}\text { Hansson \& Monsted } \\
(2008)\end{array}$ \\
\hline
\end{tabular}




\begin{tabular}{|c|c|c|}
\hline ES Categories & Conceptualisation & Authors \\
\hline \multirow{7}{*}{$\begin{array}{l}\text { (3) Frame- } \\
\text { works and } \\
\text { Models (FM), } \\
\text { ( } \mathrm{N}=14 \text { docu- } \\
\text { ments) }\end{array}$} & Evaluation models associated with ES, which use process simulation. & Ihrig (2010) \\
\hline & $\begin{array}{l}\text { Evaluation models associated with a strategic framework for entre- } \\
\text { preneurial activities and identification of four sub-dimensions of ES. }\end{array}$ & Song (2011) \\
\hline & Evaluation models associated with an ES in a broad sense. & Ihrig (2012) \\
\hline & Evaluation models associated with an ES depending on leadership. & $\begin{array}{l}\text { Jia, Wang, Zhao, \& Yu } \\
(2014)\end{array}$ \\
\hline & $\begin{array}{l}\text { Evaluation models associated with ES, using the theories of complex- } \\
\text { ity to operationalise the model. } \\
\text { Evaluation model associated with ES and the sources of competitive } \\
\text { advantage among entrepreneurial firms. }\end{array}$ & $\begin{array}{l}\text { Crawford \& Kreiser } \\
\text { (2015) } \\
\text { Johnson \& Van De (2017) }\end{array}$ \\
\hline & Evaluation models associated with ES as innovation levels. & Kim \& Boh (2017) \\
\hline & $\begin{array}{l}\text { Evaluation models associated with the entrepreneurial choice pro- } \\
\text { cess. }\end{array}$ & $\begin{array}{l}\text { Gans, Stern, \& Wu } \\
(2019)\end{array}$ \\
\hline \multirow{9}{*}{$\begin{array}{l}\text { (4) Contexts } \\
\text { and Applica- } \\
\text { tion (CA), ( } \mathrm{N}= \\
14 \text { docu- } \\
\text { ments) }\end{array}$} & Adaptation of ES with public policies. & Doh \& Pearce li (2004) \\
\hline & Adaptation of ES with HR management. & $\begin{array}{l}\text { Hayton, Hornsby, \& } \\
\text { Bloodgood (2013) }\end{array}$ \\
\hline & Adaptation of ES rapidly changing scenarios. & Page \& Wiersema (1992) \\
\hline & Adaptation of ES with changing scenarios of markets. & Dilts \& Prough (1987) \\
\hline & $\begin{array}{l}\text { ES in new business opportunities. } \\
\text { Application of ES in new businesses in a life cycle model. } \\
\text { Addresses the issues of creation, diffusion and growth of knowledge } \\
\text { and the role assigned to the dynamic entrepreneurial processes. } \\
\text { Application of ES to mature companies. }\end{array}$ & $\begin{array}{l}\text { Companys \& McMullen } \\
\text { (2007) } \\
\text { Gundry \& Kickul (2007) } \\
\text { Braunerhjelm (2008) } \\
\text { Chandra \& Yang (2011) } \\
\end{array}$ \\
\hline & $\begin{array}{l}\text { ES with accounting methods of evaluating the value of companies } \\
\text { and their capital. }\end{array}$ & Bratland (2012) \\
\hline & Application of ES and innovation in all kinds of industries. & Djordjevic (2013) \\
\hline & Application of ES in regional innovation clusters. & Feldman (2014) \\
\hline & $\begin{array}{l}\text { Application of ES integrated with entrepreneurship to increase the } \\
\text { competitiveness of enterprises. } \\
\text { Application of ES in mature companies. }\end{array}$ & $\begin{array}{l}\text { Dhilwayo (2012) } \\
\text { Roaldsen (2015) }\end{array}$ \\
\hline \multirow{11}{*}{$\begin{array}{l}\text { (5) Application } \\
\text { and Metrics } \\
\text { (AM), ( } \mathrm{N}=22 \\
\text { articles) }\end{array}$} & $\begin{array}{l}\text { Measurement of ES on the impact of industrial work. } \\
\text { One of the sources of variation in small businesses' presence is at- } \\
\text { tributed to ES developed for them. }\end{array}$ & $\begin{array}{l}\text { Stites (1985) } \\
\text { Acs, ZJ, \& Audretsch } \\
(1989)\end{array}$ \\
\hline & $\begin{array}{l}\text { Reveals strategy formulation issues and provides recommendations } \\
\text { for effective processes ES. }\end{array}$ & Karami (2012) \\
\hline & $\begin{array}{l}\text { Entrepreneurial orientation as an antecedent explanatory construct } \\
\text { of entrepreneurship within a business performance chart. }\end{array}$ & Moruku (2013) \\
\hline & $\begin{array}{l}\text { Examines the significance of innovation for organisations that follow } \\
\text { entrepreneurial orientation strategies and improved performance in } \\
\text { these organisations. }\end{array}$ & Jarrar \& Smith (2014) \\
\hline & $\begin{array}{l}\text { Orientation and entrepreneurial versus executive powers business } \\
\text { performance both have a positive influence on corporate perfor- } \\
\text { mance. }\end{array}$ & Jia et al. (2014) \\
\hline & Entrepreneurial orientation versus business performance. & Sonfield \& Lussier (2014) \\
\hline & $\begin{array}{l}\text { Theory of social networks and the resource-based view affects ES } \\
\text { and survival. }\end{array}$ & Xiao (2015) \\
\hline & $\begin{array}{l}\text { A new model of ES approaches with a procedural perspective by } \\
\text { building its link with the theory of complexity and process philoso- } \\
\text { phy and contribution to success. }\end{array}$ & Zhang (2017) \\
\hline & $\begin{array}{l}\text { Measurement of entrepreneurial strategy on innovation in compa- } \\
\text { nies with resource constraints. }\end{array}$ & Kim \& Boh (2017) \\
\hline & $\begin{array}{l}\text { Intellectual capital and new businesses versus competitive ad- } \\
\text { vantages. }\end{array}$ & $\begin{array}{l}\text { Anwar, Zaman, Khan, \& } \\
\text { Khan (2018) }\end{array}$ \\
\hline & Measurement of ES on corporate performance. & Gao, Ge, Lang, \& Xu \\
\hline
\end{tabular}




\begin{tabular}{|c|c|c|}
\hline ES Categories & Conceptualisation & Authors \\
\hline \multirow{6}{*}{$\begin{array}{l}\text { (5) Application } \\
\text { and Metrics } \\
\text { (AM), (N = } 22 \\
\text { articles) }\end{array}$} & $\begin{array}{l}\text { Entrepreneurial orientation versus generation of market value capi- } \\
\text { tal. }\end{array}$ & $\begin{array}{l}\text { (2018) } \\
\text { Gupta, Mortal, \& Yang } \\
\text { (2018) }\end{array}$ \\
\hline & $\begin{array}{l}\text { Measurement of ES on the emergence of new businesses and new } \\
\text { companies. }\end{array}$ & $\begin{array}{l}\text { Muramalla \& Al-Hazza } \\
\text { (2019) }\end{array}$ \\
\hline & Control versus running in uncertain scenarios. & $\begin{array}{l}\text { Ching, Gans, \& Stern } \\
(2019)\end{array}$ \\
\hline & $\begin{array}{l}\text { Performance of ES along with simultaneous testing of multiple busi- } \\
\text { nesses can boost performance. }\end{array}$ & $\begin{array}{l}\text { Hietaniemi \& Peltonen } \\
(2019)\end{array}$ \\
\hline & $\begin{array}{l}\text { Performance measurement versus building effective networks of ES } \\
\text { and links to external agencies. }\end{array}$ & Khan et al. (2019) \\
\hline & $\begin{array}{l}\text { Measurement of entrepreneurial orientation dimension on perfor- } \\
\text { mance and moderating roles of social capital from political and busi- } \\
\text { ness connections in the context of a transition economy. }\end{array}$ & Luu \& Ngo (2019) \\
\hline
\end{tabular}

Source: own study.

\section{(1) Economic Theory and Entrepreneurship (ETE)}

In economic literature - surprisingly, or perhaps not - the entrepreneur was left out for many decades. Entrepreneurship is an important issue and was neglected for a long time (Foss \& Lyngsie, 2011), although the situation has changed recently. The reasons for this are not entirely unrelated to how the neoclassical general equilibrium model is constructed. In the neoclassical framework, in an economy of production, agents maximise their utility by applying labour and human capital in a given set of opportunities. In the case of Keynesian theory, the entrepreneur's role was considered narrowly in expectations that determine investment. The expectations would depend on the investor's animal spirits, their level being determined by mere individual psychology. Thus, in terms of the model, the interest rate was the only variable explaining investment decisions: "Most, probably, of our decisions to do something positive, the full consequences of which will be drawn out over many days to come, can only be taken as a result of animal spirits of a spontaneous urge to action rather than inaction, and not as the outcome of a weighted average of quantitative benefits multiplied by quantitative probabilities" (Keynes, 1936, p. 161).

One of the first items to draw attention to these limitations of economic theory was Entrepreneurship in Economic Theory (Baumol, 1968) which referred to the need to integrate entrepreneurship in economic models and going beyond just maximising (or minimising) problem-solving. As a result, becoming part of other variables - even of sociological nature - to explain the factors that foster entrepreneurs' emergence in an economy. Before that, the most important consideration of the entrepreneur's role had been made by Schumpeter, who put the innovative entrepreneur in the centre of the driving forces of economic growth and progress of societies, an agent in charge of creative destruction resulting from the introduction of innovations (Schumpeter, 1934). After that, there comes the concept of competitive advantage of companies in the market over its competitors, which is shown as being dependent on lower costs or product differentiation which, in any case, implies the existence of strategies aimed at innovation and risk-taking in a durable, sustainable, and replicable manner (Porter, 1980), therefore, we can say that it would imply the existence of ESs.

Advancing in the chronology and trying to identify, in short, the most recent contributions of the literature found on this issue, we can then present some proposals concerning entrepreneurship: 1) Entrepreneurship is decisive in getting better and more efficient combinations of factors (Hoeyi \& Dzansi, 2014) and should be incorporated into the context of a reformulation of the firm's economic theory (Foss, Klein, \& Bylund, 2011); 2) Such increased efficiency derives from the entrepreneurial agent's characteristics: a) an entity that discovers and explores new opportunities; b) an organisation that creates and motivates change processes. These characteristics determine a behaviour which is guided by risk-taking, by intuition, alertness, and creation of new businesses; by leadership and the initiation of new modes of operation, by the identification of new business opportunities, and by the creation of new companies (Cuervo, Ribeiro, \& Roig-Dobón, 2007); 3) There is a broad consensus that 
entrepreneurship is a vital force in the economies of developed countries - the consensus is not evident as to what entrepreneurial activity is - most notably three transmission mechanisms through which a capital entrepreneur influences the product of economies: a) the impact of the knowledge generated; b) an increase in the competition inherent to an increase in the number of companies; c) an increase in the diversification of companies themselves (Audretsch \& Keilbach, 2004; Braunerhjelm, 2008); 4) Entrepreneurship becomes strategic entrepreneurship when an entrepreneurial action is performed in a strategic perspective, more specifically, when this involves the simultaneous search of opportunities and competitive behaviour to pursue benefits for the design and implementation of business strategies driven by wealth creation. These actions can be carried out by individuals or companies (Djordjevic, 2013). When the search inherent to entrepreneurship opportunities is combined with the demand for advantages inherent to strategic management, articulating in a collaborative process, we are in the framework of strategic entrepreneurship (Foss \& Lyngsie, 2011).

\section{(2) Concept and Theory (CT)}

To build this "concept and theory" category, 30 articles were identified and included. As can be seen, the academic silence on the role of the entrepreneur and entrepreneurial strategies of companies began to break up in the late 60s of the last century, as was said in 1999: "Research into the nature, antecedents, and effects of firm-level entrepreneurial activities has proliferated over the past 25 years" (Zahra, Jennings, \& Kuratko, 1999). Thus, these authors in the same publication - one SLR on entrepreneurship in companies - isolated 45 empirical studies on the subject, published in the 70s, 80 s and 90s, referring to Miller and Friesen (1982) proposals from Miller (1983). At the time, these were the dominant models of companies' entrepreneurship, which is consistent with the fact that these two articles today are the most cited in our survey.

Previously, the first article on the conception of ES had appeared (Murray, 1984), which was mentioned in the introduction but to which we will return. The argument about whether a strategy will have an entrepreneurial character or not is placed on a global change - a period of life of decisions of companies in which strategies are changing rapidly and more or less simultaneously. This leads the author to stress three key elements of entrepreneurial strategies: 1) continued adaptation of the company to the environment in which it operates, which is, necessarily, changeable and dynamic; 2) making decisions rupture in its internal organisational behaviour and input-output parameters of the production process; 3 ) a continued focus on change and a long-term perspective and not as an occasional response to an external shock, "a conservative company can, after all, continue entrepreneurial strategies" (Murray, 1984, p. 2).

Moreover, another decisive factor is the characteristics of entrepreneurial strategies, which can differentiate the concept's application to the established companies in confrontation with new companies. While in the first case entrepreneurial strategies arise as a process of adaptation to the environment in which companies operate, in the second scenario, new companies and/or new products will be instruments of change in the surrounding economic and technological environment itself, leading to such a change, which in turn causes structural changes in the companies (Dilts \& Prough, 1987). Kurakto and Audretsch (2013) offer a synthesis of the conceptual evolution of corporate entrepreneurship, from the 70s to the present day, anchored in the list of relevant literature on the subject. Being the first attempts at the conceptualisation of entrepreneurial strategies, this has come to be considered insufficient, as this process which "has been depicted in the literature is the failure to produce satisfyingly cumulative knowledge on the topic" (Ireland, Covin, \& Kuratko, 2009, p. 20). Our choice for this model is based on the fact that the authors, Ireland, Covin, and Kuratko (2009), place the ES at the centre of all the company's strategic action, and not as a consequence of the pursuit of any other strategic decision vector where entrepreneurship has to exist secondarily, eventually for reasons of competition in the markets. Consequently, we have a model that responds to what entrepreneurial strategies are, and elucidates factors that determine them, and clarifies the conditions for the process of implementation to be successful. We have not identified other relevant articles in opposition to this model, but rather complementary ones based on the contextual factors in the operating model and the interconnections between them. 


\section{(3) Frameworks and Models (FM)}

This set of studies included in this approach (14 documents), consists essentially of empirical studies which show tools to assess the degree of the implementation of business strategies or to assess the impacts of this implementation on the overall performance of companies or a specific element of this measure of performance. Given the conceptual framework proposed by Ireland, Covin, and Kuratko (2009, p. 40), measuring ES does not seem easy. The authors recognize this as a challenge leading them to stating that the entrepreneurial vision is easier to conceptualise than measure. Therefore, some of the evaluation models focus primarily on specific manifestations associated with entrepreneurial strategies, as innovation levels (Kim \& Boh, 2017; Miller \& Friesen, 1982; Werker, 2003); others put the competence of the leadership at the centre of analysis (Endres \& Weibler, 2017; Hansson \& Mønsted, 2008; Jia, Wang, Zhao, \& Yu, 2014; Ray, 1993). Some authors try to assess the ES in a broad sense (Dess, Lumpkin, \& Covin, 1997; Ihrig, 2010; Johnson \& Van De, 2017; Miller, 1983); others use the theories of complexity to operationalise Ireland, Covin, and Kuratko's (2009) model (Crawford \& Kreiser, 2015).

In addition, some models use simulation processes (Ihrig, 2010), recent tools of artificial intelligence (AI), and neural networks (DaPeng, Ning, \& Songting, 2016) to obtain results in the measurement of entrepreneurial strategies. Finally, there are also studies that present econometric evaluations of certain specific impacts (Lee \& Liu, 2018), both of the context factors of entrepreneurial strategies and their macroeconomic impact on the economy as a whole (Werker, 2003). Faced with such a diversity of instruments, we can conclude that there is no uniform method of the assessment of ES that can be used in all types of companies and markets. The ES deemed most appropriate does not have to be the same for all companies as it is affected by the specific assets (patents, own skills, brands, talent, etc.) each company has. "Strategic management requires companies to establish and exploit competitive advantages in a specific environmental context, while entrepreneurship promotes the search for competitive advantages through products, processes, and innovations in the market" (Kuratko \& Audretsch, 2009, p. 5). It is the integration of entrepreneurship with a strategy that defines the ES.

\section{(4) Contexts and Applications (CA)}

This set of theoretical articles (14 documents) is intended to study the application of ES in specific contexts, either problematising the implementation of ES or linking this implementation to certain variables characterising the environment in which companies operate. The variability of the studies is large, and their common denominator is their relationship with the items included in the four major groups proposed in the conceptual reference model of ES that was previously assumed, namely: 1) the external environment conditions; 2 ) organisational pro-entrepreneurship architecture; 3 ) individual entrepreneurial cognition; 4) entrepreneurial processes and behaviours.

Thus, we have studies on the connection/adaptation of entrepreneurial strategies with public policy (Doh \& Pearce II, 2004); with the human resources management (Hayton, Hornsby, \& Bloodgood, 2013); with rapidly changing technology scenarios (Page Jr. \& Wiersema, 1992); with changing market scenarios (Dilts \& Prough, 1987); with the research and discovery of new business opportunities (Companys \& McMullen, 2007), and with the accounting methods of evaluating the value of companies and its capital (Bratland, 2012). Additionally, there are also studies on the application of entrepreneurial strategies in specific entities or certain types of companies, as in public departments (Page, 2003); in mature companies (Roaldsen, 2015); in regional innovation clusters (Feldman, 2014); in new companies as part of their integration into a business lifecycle model (Gundry \& Kickul, 2007). Furthermore, those studies are connected with individual cognition of entrepreneurial decision-makers in terms of leadership and psychology (Felin \& Zenger, 2009).

\section{(5) Applications and Metrics (AM)}

This group of empirical studies (22 documents), both quantitative and qualitative, tries to measure: 1 ) the impact of certain context variables on the design and implementation of entrepreneurial strategies; 
2) or the impact of entrepreneurial strategies on various economic attributes of companies; 3 ) or interconnections between certain context variables and from there discuss the final effect on entrepreneurial strategies and businesses. The range of studies is large so that the variables represented in the studies on interconnections will be derived, among others, from: a) culture versus innovation (Sayan \& Dinesh, 2012); b) imitation versus innovation (Ching, 2013); c) orientation versus entrepreneurial behaviour of an entrepreneur (Kemepade Moruku, 2013); d) guidance versus entrepreneurial business performance; e) entrepreneurial education versus strategic decision making (Sonfield \& Lussier, 2014); f) intellectual capital and new businesses versus competitive advantages (Anwar, Zaman Khan, \& Khan, 2018); g) control versus running in uncertain scenarios (Ching, Gans, \& Stern, 2019). With regards to measurement referring to entrepreneurial strategies they will be on the impact of: a) manufacturing work (Stites 1985); b) on business performance (Gao, Ge, Lang, \& Xu, 2018); c) on the emergence of new businesses and new enterprises (Muramalla \& Al-Hazza, 2019); on innovation in companies with constrained resources (Kim \& Boh, 2017). Finally, the interaction between entrepreneurial strategies and some context variables is quantitatively studied (Gupta, Moral, \& Yang, 2018; Hietaniemi \& Peltonen; Khan, Li, Safdar, \& Khan, 2019; Jia, Wang, Zhao, \& Yu, 2014; Xiao, 2015; Zhang, 2017).

\section{CONCLUSIONS}

This literature review can highlight the gap in theorising entrepreneurial strategies (ES), their conceptualisation, and the fundamentals found in the literature. Our analysis is the conceptualisation focused on five ES foundations: 1) Economic Theory and Entrepreneurship (ETE); 2) Concept and Theory (CT); 3) Frameworks and Models (FM); 4) Contexts and Applications (CA); and 5) Application and Metrics (AM). As a result, we have built a model of interactions (Figure 3 ) that summarises the five foundations identified throughout the literature review.

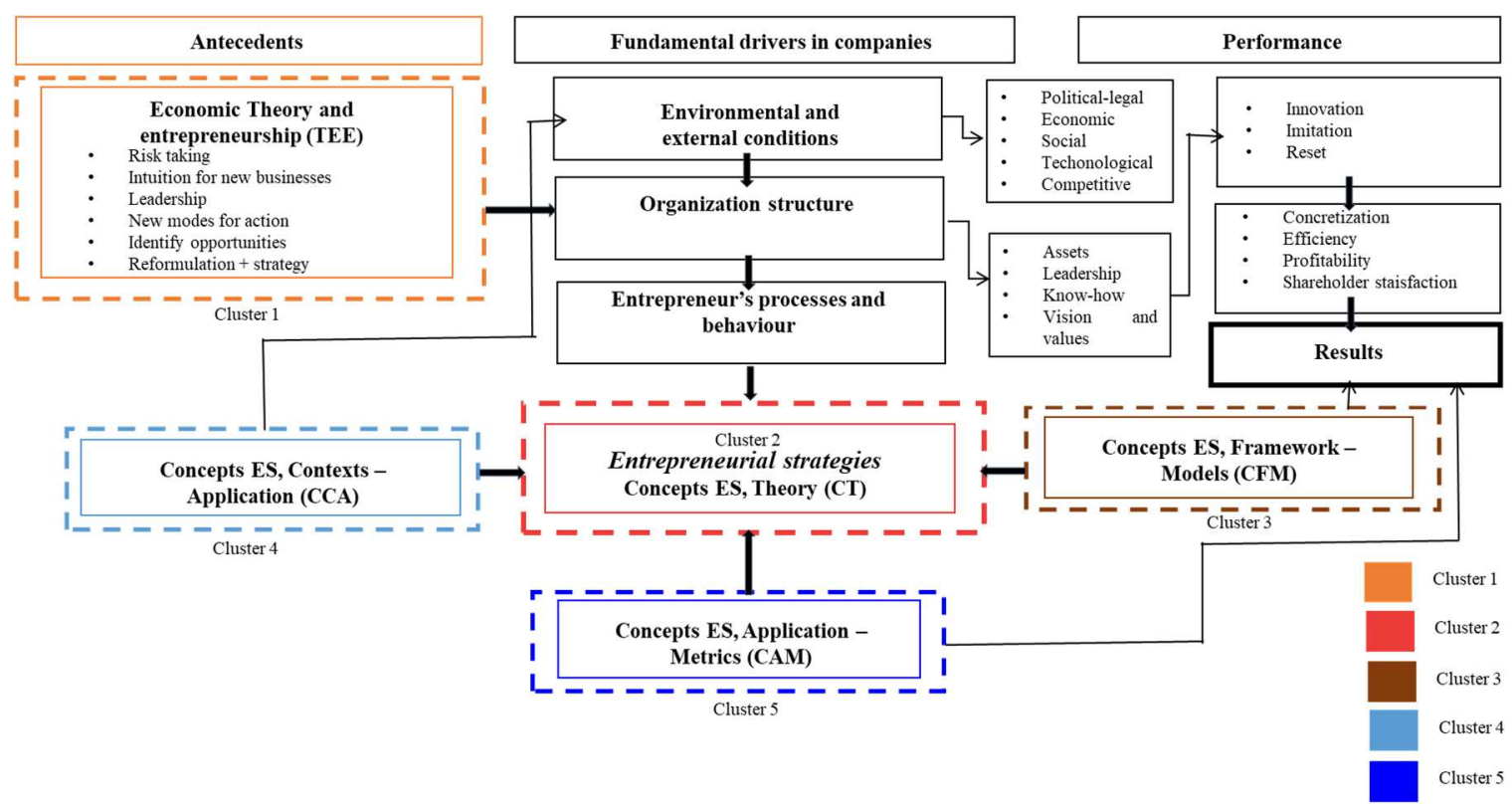

Figure 3. The conceptual model followed in the path of the SRL Source: own elaboration.

In summary and placing the focus on the conceptual model of ES we elect as having the greatest explanatory capacity (Ireland, Covin, \& Kuratko, 2009), we will present some proposals that we consider to have been acquired for each ES foundation: 1) The concept of an enterprising entrepreneur created by Schumpeter added a new dimension to economic theory. Entrepreneurs are the economic agents being proactive in research, promotion and implementation of innovation, introducing changes that radically alter the structure of the economic system. Entrepreneurial behaviour is guided by the recognition of new opportunities and the consequent exploitation of these opportunities, and this marked process 
for entrepreneurs' beliefs, attitudes and values, which ultimately determine their entrepreneurial vision from which the characteristics of the need for realisation, willingness to take risks, and self-confidence emerge; 2 ) In the context of the company, the competitive business management is combined with entrepreneurship, we move to the conceptual level of strategic entrepreneurship, to the conceptual level of entrepreneurial strategies; 3) Achieving entrepreneurial strategies will lead companies to increase their results and performance, whether existing ones or emerging small and medium-sized innovative companies, depending on leadership, innovation in different contexts and associated with the entrepreneurial choice process; 4) Several conditions positively influence entrepreneurial behaviour, then the guidance for entrepreneurship (EO) and the implementation level of entrepreneurial strategies - higher education, training, goods market efficiency, labour market efficiency, technological readiness, and size of the market; 5) The performance increase is negatively correlated with the degree of uncertainty inherent to the environment in which companies operate (context variables), but positively correlated with the level and the speed of entrepreneurial learning in an ongoing trial and sequent proactive adaptation process. A high level of entrepreneurial strategies in more business structures generates a higher level of economic development, as demonstrated by several studies that we assessed.

This SLR allows to fill the gap in the concept of ES and its theoretical foundations, it also demonstrates that the diversity of research has been carried out - with conclusions not identical - on the subject of entrepreneurship and entrepreneurial strategies. This subject is far from being exhausted, either in theoretical or in empirical terms.

Regarding future research lines, when the literature points out the environmental factors that can be taken as limiting the implementation of entrepreneurial strategies, there is practically no reference to financial constraint. It is assumed that a clear entrepreneurial orientation at the organisation level is financially assured. The existence and support of an ES vision within the organisation necessarily implies an acknowledgment and assumption of costs, their measurement function, and a financial plan capable of supporting them continuously and for an uncertain period from which a return can be expected, respectively. Undoubtedly, these issues are relevant in established companies, when creating new companies, and during the emergence of new business. Therefore, in our view, it should be taken into account in future research lines. We assume some limitations in this research, particularly the use of only two databases for the collection of items that constitute the systematic literature review. Finally, other limiting drivers of the review may be the exclusion/inclusion criteria, especially the time constraints.

\section{REFERENCES}

Acs, Z., \& Audretsch, D. (1989). Entrepreneurial strategy and the presence of small Firms. Small Business Economics, 1(3), 193-213. https://doi.org/10.1007/BF00401857

Anwar, M., Khan, S.Z., \& Khan, N.U. (2018). Intellectual Capital, Entrepreneurial Strategy and New Ventures Performance: Mediating Role of Competitive Advantage. Business \& Economic Review, 10(1), 63-94. https://doi.org/10.22547/BER/10.1.3

Anderson, B., Covin, J., \& Slevin, D. (2009). Understanding the relationship between entrepreneurial orientation and strategic learning capability: an empirical investigation. Strategic Entrepreneurship Journal, 3(3), 218240. https://doi.org/10.1002/sej.72

Audretsch, D.B., \& Keilbach, M. (2004). Entrepreneurship Capital and Economic Performance. Discussion Papers on Entrepreneurship. Growth and Public Policy, 1-24. https://doi.org/10.1080/0034340042000280956

Baumol, W. (1968). Entrepreneurship in Economic Theory. The American Economic Review, 58(2), 64-71. Retrieved from https://www.jstor.org/stable/1831798 on November 20, 2020.

Braunerhjelm, P. (2008). Entrepreneurship, Knowledge and Economic Growth. Foundations and Trends ${ }^{\circledR}$ in Entrepreneurship, 4(5), 451-533. https://doi.org/10.1561/0300000013

Chandra, Y., \& Yang, S.-J. (2011). Managing Disruptive Innovation: Entrepreneurial strategies and tournaments for corporate longevity. Journal of General Management, 37(2), 23-50. https://doi.org/10.1177/030630701103700202

Ching, K. (2013). Innovation or Imitation? Business Models and Entrepreneurial Strategy. Academy of Management Proceedings. https://doi.org/10.5465/ambpp.2013.13272abstract

Ching, K., Gans, J., \& Stern, S. (2019). Control versus execution: Endogenous appropriability and entrepreneurial strategy. Industrial and Corporate Change, 28(2), 389-408. https://doi.org/10.1093/icc/dty040 
Companys, Y.E., \& McMullen, J.S. (2007). Strategic entrepreneurs at work: The nature, discovery, and exploitation of entrepreneurial opportunities. Small Business Economics, 28(4), 301-322. https://doi.org/10.1007/s11187-006-9034-x

Crawford, G.C., \& Kreiser, P.M. (2015). Corporate entrepreneurship strategy: extending the integrative framework through the lens of complexity science. Small Business Economics, 45(2), 403-423. https://doi.org/10.1007/s11187-015-9637-1

Cuervo, Á., Ribeiro, D., \& Roig, S. (2007). Entrepreneurship: Concepts, Theory and Perspective. Introduction. In Á. Cuervo, D. Ribeiro, \& S. Roig (Eds.), Entrepreneurship (pp. 1-23). Berlin, Heidelberg: Springer.

DaPeng, Y., Ning, C., \& Songting, P. (2016). Enterprise innovation and entrepreneurial development strategy in perspective of organizational behavior positive. Journal of Computational and Theoretical Nanoscience, 13(12), 9353-9357. https://doi.org/10.1166/jctn.2016.5846

Denyer, D., \& Tranfield, D. (2009). Producing a systematic review. In D. Buchanan \& A. Bryman (Eds.), Handbook of organizational research methods (pp. 671-689). Sage Publications Ltd.

Dess, G., Lumpkin, G., \& Covin, J. (1997). Entrepreneurial strategy making and firm performance: tests of contingency and configurational models. Strategic Management Journal, 18(9), 677-695. https://doi.org/10.1002/(SICI)1097-0266(199710)18:9<677::AID-SMJ905>3.0.CO;2-Q

Dilts, J., \& Prough, G. (1987). Entrepreneurial Strategies for Managing the Changing Competitive Environment. Business Forum, 12(4), 30-33.

Djordjevic, B. (2013). Strategic entrepreneurship: Issues and challenges. Mediterranean Journal of Social Sciences, 4(7), 155-163. https://doi.org/10.5901/mjss.2013.v4n7p155

Doh, J., \& Pearce II, J. (2004). Corporate Entrepreneurship and Real Options in Transitional Policy Environments: Theory Development. Journal of Management Studies, 41(4), 645-664. https://doi.org/10.1111/j.14676486.2004.00448.x

Drucker, P. (1985). Entrepreneurial Strategies. California Management Review, 27(2), 9-25.

Endres, S., \& Weibler, J. (2017). Towards a Three-Component Relational Model of Social Constructionist Leadership: A Systematic Review and Critical Interpretive Synthesis. International Journal of Management Reviews, 19(2), 214-236. https://doi.org/10.1111/ijmr.12095

Feldman, M. (2014). The character of innovative places: Entrepreneurial strategy, development economic, and prosperity. Small Business Economics, 43(1), 9-20. https://doi.org/10.1007/s11187-014-9574-4

Felin, T., \& Zenger, T. (2009). Entrepreneurs the theorists: on the origins of novel strategies and collective beliefs. Strategic Entrepreneurship Journal, 3(2), 127-146. https://doi.org/10.1002/sej.67

Foss, N., \& Lyngsie, J. (2011). The emerging strategic entrepreneurship field: Origins, key tenets, and research gaps. In Handbook of Organizational Entrepreneurship. https://doi.org/10.2139/ssrn.1747711

Foss, N., \& Lyngsie, J. (2011). The Emerging Strategic Entrepreneurship Field: Origins, Key Tenets and Research Gaps. Institut for Strategic Management and Globalization. SMG Working Paper No. 7/2011

Foss, N., Klein, P., \& Bylund, P. (2011). Entrepreneurship and the Economics of the Firm. Handbook on Organizational Entrepreneurship. https://doi.org/10.4337/9781849803786.00012

Gans, J., Stern, S., \& Wu, J. (2019). Foundations of entrepreneurial strategy. Strategic Management Journal, 4O(5), 736-756. https://doi.org/10.1002/smj.3010

Gao, Y., Ge, B., Lang, X., \& Xu, X. (2018). Impacts of proactive and entrepreneurial orientation strategy on entrepreneurial performance: An empirical research. Technological Forecasting and Social Change, 135, 178187. https://doi.org/10.1016/j.techfore.2017.11.019

Gundry, L., \& Kickul, J. (2007). Entrepreneurship strategy: Changing patterns in new venture creation, growth, and reinvention. SAGE Publications Inc.

Gupta, V., Mortal, S., \& Yang, T. (2018). Entrepreneurial orientation and firm value: Does managerial discretion play a role?. Review of Managerial Science, 12(1), 1-26. https://doi.org/10.1007/s11846-016-0210-3

Hayton, J., Hornsby, J., \& Bloodgood, J. (2013). Entrepreneurship: a review and schedule for future research. Management, 16(4), 381-409. https://doi.org/10.3917/mana.164.0381

Hietaniemi, L., \& Peltonen, J. (2019). Parallel Experimentation as Entrepreneurial Strategy: Effects on Innovativeness, Exit and Resourcing. Academy of Management Annual Meeting Proceedings, 1-1-1. https://doi.org/10.5465/AMBPP.2019.14554abstract

Hind, C., \& Steyn, R. (2015). Corporate entrepreneurship - Distilling the concept. The Southern African Journal of Entrepreneurship and Small Business Management, 7(1), 69. https://doi.org/10.4102/sajesbm.v7i1.7

Hitt, M., Camp, M., \& Sexton, D. (2001). Strategic Entrepreneurship: Entrepreneurial Strategies for Wealth Creation. Strategic Management Journal, 22(6-7), 479-491. https://doi.org/10.1002/smj.196 
Hoeyi, P., \& Dzansi, D. (2014). Entrepreneurship - The Productive Ingenuity of the Human Factor in an Ambiguous Environment. Mediterranean Journal of Social Sciences, 5(23), 11-19. https://doi.org/10.5901/mjss.2014.v5n23p11

Ihrig, M. (2010). Investigating entrepreneurial strategies via simulation. Proceedings - 24th European Conference on Modeling and Simulation, ECMS 2010, (pp. 57-66).

Ireland, R., Covin, J., \& Kuratko, D. (2009). Conceptualizing Entrepreneurship Corporate Strategy. Entrepreneurship Theory and Practice, 33(1), 19-46. https://doi.org/10.1111/j.1540-6520.2008.00279.x

Jia, J., Wang, G., Zhao, X., \& Yu, X. (2014). Exploring the relationship between entrepreneurial orientation and performance corporate: The role of competency of executives in entrepreneurial-oriented corporations. Nankai Business Magazine International, 5(3), 326-344. https://doi.org/10.1108/NBRI-05-2014-0024

Johnson, S., \& Van De, V. (2017). A Framework for Entrepreneurial Strategy In M.A. Hitt, R. Duane Ireland, S.M. Camp, \& D.L. Sexton (Eds.), Strategic Entrepreneurship (pp. 66-85). https://doi.org/10.1002/9781405164085.ch4

Karami, A. (2012). Strategy formulation in entrepreneurial Firms. Ashgate Publishing, Ltd.

Kemepade Moruku, R. (2013). Does entrepreneurial orientation predict entrepreneurial behavior?. International Journal of Entrepreneurship, 17, 41-60. https://doi.org/10.29322/IJSRP.9.11.2019.p95112

Keynes, J. (1936). The General Theory of Employment, Interest and Money. London: Macmillan.

Khan, N., Li, S., Safdar, M., \& Khan, Z. (2019). The Role of Entrepreneurial Strategy, Network Ties, Human and Financial Capital in New Venture Performance. Journal of Financial Risk and Management, 12(1), 41. https://doi.org/10.3390/jrfm12010041

Kim, J., \& Boh, W. (2017). Entrepreneurial Strategies: Impact on Innovation Performance for Resource-Constrained Firms. Proceedings of Academy of Management, 1, 15376. https://doi.org/10.5465/AMBPP.2017.201

Kuratko, D., \& Audretsch, D. (2013). Clarifying the domains of corporate entrepreneurship. International Entrepreneurship and Management Journal, 9(3), 323-335. https://doi.org/10.1007/s11365-013-0257-4

Kuratko, D., \& Audretsch, D. (2009). Strategic Entrepreneurship: Exploring Different Perspectives of an Emerging Concept. Entrepreneurship Theory and Practice, 33, 1-17. https://doi.org/10.1111/j.1540-6520.2008.00278.x

Kuratko, D., Covin, J., \& Garrett, R. (2009). Corporate venturing: Insights from current performance. Business Horizons, 52(5) 459-467. https://doi.org/10.1016/j.bushor.2009.05.001

Lee, T., \& Liu, H.-M. (2018). How do Firms with Management Ability Promote Competitive Advantages? An Integrated Model from Entrepreneurial Strategy Making and Internal Resources. Entrepreneurship Research Journal, 8(2), https://doi.org/10.1515/erj-2017-0071

Luu, N., \& Ngo, L. (2019). Entrepreneurial orientation and social ties in transitional economies. Long Range Planning, 52(1), 103-116. https://doi.org/10.1016/j.Irp.2018.04.001

Meyer, G., \& Heppard, K. (2000). Entrepreneurial Strategies: The Dominant Logic of Entrepreneurship. In G. Dale Myer (Eds.), Entrepreneurship as Strategy: Competing on the Entrepreneurial Edge, SAGE Publications, Inc.

Miller, D. (1983). The Correlates of Entrepreneurship in Three Types of Firms. Management Science, 29(7), 770791. https://doi.org/10.1287/mnsc.29.7.770

Miller, D., \& Friesen, P. (1982). Innovation in Conservative and Entrepreneurial Firms: Two Models of Strategic Momentum. Strategic Management Journal, 3(1), 1-25. https://doi.org/10.1002/smj.4250030102

Morris, M., Kuratko, D., \& Covin, J. (2008). Corporate entrepreneurship and innovation: entrepreneurial development Within organizations. Mason, $\mathrm{OH}$ : Thomson / South-Western.

Muramalla, V., \& Al-Hazza, A. (2019). Entrepreneurial strategies and business factors stimulate the startup of Tech. International Journal of Financial Research, 10(3), 360-370. https://doi.org/10.5430/ijfr.v10n3p360

Murray, J. (1984). The concept of entrepreneurial strategy. Strategic Management Journal, 5(1), 1-13. https://doi.org/10.1002/smj.4250050102

Nolan, C.T., \& Garavan, T.N. (2016). Human Resource Development in SMEs: A Systematic Review of the Literature. International Journal of Management Reviews, 18(1), 85-107. https://doi.org/10.1111/ijmr.12062

Omotosho, S., \& Anyigba, H. (2019). Conceptualising corporate entrepreneurial strategy: The contingency and agency collaborative approach. Journal of Strategy and Management, 12(2), 19. https://doi.org/10.1108/JSMA-05-2018-0046

Ott, T., Eisenhardt, K., \& Bingham, C. (2017). Strategy Formation in Entrepreneurial Settings: Insights Past and Future Directions. Strategic Entrepreneurship Journal, 11(3), 306-325. https://doi.org/10.1002/sej.1257

Page, Jr., R., \& Wiersema, M. (1992). Entrepreneurial and radical innovation strategies: The punctuated disequilibrium approach. Journal of High Technology Management Research, 3(1), 17. https://doi.org/10.1016/1047-8310(92)90005-M

Page, S. (2003). Entrepreneurial Strategies for Managing Interagency Collaboration. Journal of Public Administration Research and Theory, 13(3), 311-340. Retrieved from https://www.jstor.org/stable/3525852 on November 20, 2020. 
Porter, M. (1980). Competitive strategy: techniques for analyzing industries and competitors. Free Press.

Roaldsen, I. (2015). The business model and entrepreneurial strategies: the case of SMEs in mature industries. In I. Roaldsen (Ed.), Developing, Shaping and Growing Entrepreneurship (p. 25).

Sayan, B., \& Dinesh, K. (2012). Power distance: a deterrent or a facilitator for innovation. International Journal of Business Excellence, 5(6), 677-705. https://doi.org/10.1504/IJBEX.2012.049541

Schumpeter, J. (1934). The theory of economic development: an inquiry into profits, capital, credit, interest, and the business cycle. New Brunswick (U.S.A) and London (U.K.): Transaction Publishers.

Sonfield, M., \& Lussier, R. (2014). The influence of the entrepreneur's education level on strategic decision making. Journal of Small Business Strategy, 24(1), 19-28. Retrieved from https://libjournals.mtsu.edu/index.php/jsbs/article/view/190 on November 19, 2020.

Stites, R. (1985). Industrial the Work an Entrepreneurial Strategy. Modern China, 11(2), $227-246$. https://doi.org/10.1177/009770048501100204

Van Geenhuizen, M. (2004). Cities and cyberspace: New entrepreneurial strategies. Regional Entrepreneurship and Development, 16(1), 5-19. https://doi.org/10.1080/0898562042000205009

Wales, W. (2016). Entrepreneurial orientation: A review and synthesis of promising research directions. International Small Business Journal, 34(1), 3-15. https://doi.org/10.1177/0266242615613840

Werker, C. (2003). Innovation, market performance, and competition: Lessons from the product life cycle model. Technovation, 23, 281-290. https://doi.org/10.1016/S0166-4972(01)00109-2

Xiao, Y. (2015). Entrepreneurial Network and Entrepreneurial Strategy Formation. Academy of Management Annual Meeting Proceedings, 1-11. https://doi.org/10.5465/ambpp.2015.15832abstract

Zahra, S., Jennings, D., \& Kuratko, D. (1999). The Antecedents and Consequences of Firm-Level Entrepreneurship: The State of the Field. Entrepreneurship Theory and Practice, 24(2), 45-65. https://doi.org/10.1177/104225879902400205

Zhang, H. (2017). Complexity absorption: Procedural strategic approach to corporate entrepreneurship strategy. Frontiers of Business Research in China, 11(1), https://doi.org/10.1186/s11782-017-0015-5 


\section{Authors}

The contribution share of authors is in equal proportions.

\section{Lídia Caldeira Branco}

PhD Candidate in Management, Portucalense University, Porto (Portugal). Her research interests include business management.

Correspondence to: Lídia Caldeira Branco, PhD Candidate, Portucalense University, Management and Economics Department, Rua Dr. António Bernardino de Almeida n. 541/619 | 4200-072 Porto, Portugal, e-mail: lidia.branco@hotmail.com

ORCID (1) http://orcid.org/0000-0002-0212-2525

\section{João J. Ferreira}

PhD in Management, University of Beira Interior \& NECE - Research Unit in Business Science. His research interests include strategy and entrepreneurship, strategic entrepreneurship, strategic management.

Correspondence to: Prof. João Ferreira, PhD, University of Beira Interior, Management and Economics Department, Estrada do Sineiro, Polo IV, Covilha, Portugal, e-mail: jjmf@ubi.pt

ORCID 다 http://orcid.org/0000-0002-5928-2474

\section{Shital Jayantilal}

PhD in Management, Portucalense University \& REMIT - Research on Economics, Management and Information Technologies. Her research interests include strategy, strategic management.

Correspondence to: Prof. Shital Jayantilal, PhD, Portucalense University, Management and Economics Department, Rua Dr. António Bernardino de Almeidan.o 541/619 | 4200-072 Porto, Portugal, e-mail: shital@upt.pt ORCID (1) http://orcid.org/0000-0002-3355-876X

\section{Conflict of Interest}

The authors declare that the research was conducted in the absence of any commercial or financial relationships that could be construed as a potential conflict of interest.

\section{Copyright and License}

This article is published under the terms of the Creative Commons

Attribution - NoDerivs (CC BY-ND 4.0) License

http://creativecommons.org/licenses/by-nd/4.0/ 